\title{
PEMANFAATAN TEKNOLOGI LOCATION BASED SERVICE (LBS) UNTUK INFORMASI DAN PENCARIAN WILAYAH PERIKANAN DI BENGKULU SELATAN
}

\author{
${ }^{1}$ Ardi Wijaya, ${ }^{2}$ Chahima Gustina \\ ${ }^{1,2}$ Universitas Muhammadiyah Bengkulu, Indonesia \\ ${ }^{1}$ ardiwijaya@umb.ac.id; ${ }^{2}$ chahimagustina99@gmail.com
}

\section{Article Info}

\section{Article history:}

Received, 18-06-2021

Revised, 21-06-2021

Accepted, 28-06-2021

\section{Kata Kunci:}

Location

Based

Service, GPS, (Global

Positioning System), android,

lokasi.

\begin{abstract}
ABSTRAK
Perkembangan teknologi yang begitu pesat sangat mempengaruhi pola hidup manusia.Teknologi yang semakin canggih menuntut Teknologi yang semakin canggih menuntut manusia menciptakan alat-alat yang mempermudah pekerjaan manusia. Salah satunya adalah pencarian wilayah perikanan. Pencarian lokasi user menggunakan GPS (Global Positioning System) menentukan letak wilayah perikanan. Dengan menggunakan Location Based Service diharapkan dapat mengatasi masalah pencarian wilayah perikanan.Di dalam skripsi ini akan membahas mengenai pencarian wilayah perikanan dimana pencarian wilayah perikanan menggunakan Location Based Service. Melalui bantuan Location Based Service yang akan membantu mengetahui keberadaan wilayah perikanan ke dalam smartphone berbasis android. Hasil dari aplikasi yang dibangun adalah sebuah aplikasi smartphone berbasis android yang dapat mengetahui wilayah perikanan menggunakan Location Based Service. Dengan memanfaatkan teknologi Location Based Service juga, pengguna lebih cepat Karena menggunakan Location Based service untuk mengetahui wilayah - wilayah perikanan yang ada di Bengkulu Selatan dengan menggunakan smartphone berbasis android .Dimana hasil ini di dapat kan dari pengujian UAT (user Aceptance Test) ini memiliki persentase $80 \%$ dari 20 user yang dilakukan. Selanjutnya untuk tidak sesuai memiliki persentasi sebesar $20 \%$ dari 20 pengujian yang dilakukan.
\end{abstract}

\begin{abstract}
Technological developments rapidly and affect of changes in human lifestyle. The demand of it is increasingly sophisticated technology that cause humans create tools that facilitate human work. One of them is searching location by using GPS (Global Positioning System). It determines the user's location by using Location Based Service. It is expected to overcome the problem of user in searching location. This paper discusses the user searches location by using Location Based Service. Through the help of Location Based Service will be pinned and will help to determine where the location of a user to their android based smartphones. The results can be obtained from the User Acceptance Test (UAT). It has a percentage of $80 \%$ of the 20 users performed. Furthermore, it is not appropriate to have a percentage of $20 \%$ of 20 peers.
\end{abstract}

This is an open access article under the CC BY-SAlicense.

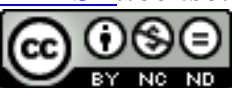

\footnotetext{
Penulis Korespondensi:

Chahima Gustina,

Program Studi Teknik Informatika,

Universitas Muhammadiyah Bengkulu,

Email: chahimagustina99@gmail.com
} 


\section{PENDAHULUAN}

Perikanan budidaya saat ini sudah mulai berkembang, Peningkatan produksi terus terjadi yang disebabkan oleh naiknya permintaan pasar terhadap produk perikanan darat ini. Begitu juga di Provinsi Bengkulu. Usaha perikanan budidaya perikanan dalam beberapa tahun terakhir meningkat signifikan, dan salah satu wilayah yang cukup berpotensi adalah Kabupaten Bengkulu Selatan. Di kabupaten ini, kecamatan yang dinilai memiliki prospek tinggi adalah Kecamatan Seginim. Dari 11 kecamatan yang ada di Kabupaten Bengkulu Selatan, Kec. Seginim memiliki lahan usaha budidaya perikanan air tawar terluas. Produksi perikanan darat pada tahun 2010 mengalami kenaikan dari tahun 2009 menjadi 2.156,08 ton dengan nilai 26,3 milyar rupiah. Berikut grafik dan data terkait produksi perikanan budidaya/air tawar di Kabupaten Bengkulu Selatan [1]

Lokasi peternakan ini mayoritasnya berada didaerah Seginim dan Air Nipis, ikan yang diternak kebanyakan ikan nila dan ikan mas. Melihat begitu pesatnya perkembangan perikanan di berbagai desa, sehingga menyulitkan mencari informasi untuk masyrakat mengetahui letak lokasi peternakan ikan. Maka dari itu sangat memungkinkan untuk dibangun aplikasi yang akan memfasilitasi informasi dan pencarian wilayah perikanan yang berada di Seginim dan Air Nipis dalam tampilan sebuah peta.

Dengan kemajuan teknologi khususnya dibidang mobile, memungkinkan penyebar luasan informasi yang sangat cepat dengan berbagai perangkat mobile yang ada. Tidak hanya itu saja, teknologi mobile juga sudah terintegrasi untuk menentukan lokasi yang melibatkan GPS. Hal ini menjadikan sebuah kebutuhan yang luar biasa untuk penyebaran informasi dengan mobile Locationbased Service. Location based service (LBS) atau layanan berbasis lokasi adalah layanan di android yang memungkinkan aplikasi dapat melacak lokasi pemakai yang sedang menggunakan smartphone. Melalui layanan ini, informasi lokasi pemakaian mencari rute jalan, atau lainnya di peta Google Map [2].

Tujuan penelitian ini adalah membangun aplikasi sebagai media informasi perikanan yang dapat memudahkan pengguna untuk mengetahui jenis-jenis ikan dan letak lokasi wilayah perikanan yang terdapat di Bengkulu Selatan.

\section{A. Aplikasi}

Aplikasi adalah penggunaan dalam suatu komputer, intruksi (instruction) atau pernyataan (statement) yang disusun sedemikian rupa sehingga computer dapat memproses input menjadi output Aplikasi dapat diartikan juga sebagai program komputer yang dibuat untuk menolong manusia dalam melakukan tugas tertentu. Aplikasi merupakan software yang berfungsi untuk melakukan berbagai bentuk pekerjaan atau tugas-tugas tertentu seperti penerapan, penggunaan dan penambahan data. [3]

\section{B. Location Based Service (LBS)}

Location Based Service (LBS) mengacu pada "sekumpulan aplikasi yang mengeksplorasi pengetahuan atau informasi dari lokasi geografis perangkat mobile untuk mendapatkan layanan berdasarkan informasi tersebut". [4]

Location Based Service atau disingkat LBS adalah kemampuan untuk mencari lokasi geografis dari mobile device dan menyediakan layanan berdasarkan lokasi yang diperolehnya [5]. Berdasarkan posisi pengguna memungkinkan penerapan LBS untuk menemukan lokasi-lokasi penting wisata seperti restoran, toko, hotel, situs sejarah-budaya bunga, memverifikasi cuaca dan kondisi lalu lintas, buku tiket untuk acara-acara perjalanan atau budaya, menghitung rute, atau mendapatkan informasi wisata lainnya [6].

Location based service atau LBS memiliki kemampuan untuk mencari lokasi geografis dari mobile device dan menyediakan layanan berdasarkan lokasi yang diperolehnya. Konsep location based service (LBS) ini menghasilkan layanan informasi mengenai lokasi keberadaan user. Location Based Service (LBS) dapat diklasifikasikan menjadi tiga jenis, yaitu :

a) Local Informasi

Memunginkan pengguna untuk mencari layanan di sekitar mereka

b) Traffic and Tracking Informasi 
Berfokus kepada pelacak asset atau manusia

c) General Services

Menggunakan data pengguna untuk mendapatkan informasi yang diperlukan oleh pengguna itu sendiri.

\section{Komponen Location Based Service (LBS)}

Terdapat empat komponen pendukung utama dalam teknologi layanan berbasis Lokasi, yaitu :

1.) Piranti mobile

2.) Jaringan komunikasi

3.) Komponen positioning (Penunjuk Posisi)

4.) Penyedia layanan dan konten (Service and content Provider)

5.) Penyedia data dan konten

C. Wilayah Perikanan

Kabupaten Bengkulu Selatan merupakan wilayah perikanan yang faktor lingkungannya belum tercemar oleh limbah. Khususnya daerah Seginim dan Air Nipis yang merupakan daerah peternak ikan yang sistem produksinya itu melalui usaha kolam air deras. Ikan yang dihasilkan oleh para peternak kebanyakan yaitu ikan nila dan ikan mas. Hasilkan produksi ikan tersebut dipasarkan baik didaerah Bengkulu Selatan maupun diluar Kota.

Lokasi peternakan ini mayoritasnya berada didaerah Seginim dan Air Nipis, ikan yang diternak kebanyakan ikan nila dan ikan mas. Melihat begitu pesatnya perkembangan perikanan di berbagai desa, sehingga menyulitkan mencari informasi untuk masyrakat mengetahui letak lokasi peternakan ikan. Maka dari itu sangat memungkinkan untuk dibangun aplikasi yang akan memfasilitasi informasi dan pencarian wilayah perikanan yang berada di Seginim dan Air Nipis dalam tampilan sebuah peta.

\section{Android}

Android merupakan salah satu system operasi yang sangat berkembang saat ini, dengan berbasiskan Linux system operasi ini dirancang untuk mengembangkan perangkat seluler layar sentuh seperti smartphone dan juga komputer tablet. Android menyediakan platform terbuka bagi para pengembang untuk menciptakan aplikasi untuk digunakan oleh bermacam piranti gerak [7].

\section{E. Perangkat Lunak Pendukung}

Perangkat Lunak Pendukung Berikut adalah perangkat lunak pendukung dalam penunjang pembangunan aplikasi yang akan di bangun [8].

\section{Android studio}

Android studio adalah IDE (Integrated Development Environment) resmi untuk pengembangan aplikasi Android dan bersifat open source atau gratis. Peluncuran Android Studio ini diumumkan oleh Google pada 16 mei 2013 pada event Google I/O Conference untuk tahun 2013. Sejak saat itu, Android Studio mengantikan Eclipse sebagai IDE resmi untuk mengembangkan aplikasi android.

\section{Java Development Kit (JDK)}

Java Development Kit (JDK) adalah sekumpulan perangkat lunak yang dapat kamu untuk mengembangkan perangkat lunak yang berbasis Java, sedangkan JRE adalah sebuah implementasi dari Java Virtual Machine yang benarbenar digunakan untuk menjalankan program java. Baisanya, setiap JDK berisi satu atau lebih JRE dan berbagai alat pengembangan lain seperti sumber compiler java, bundling, debuggers, development libraries dan lain sebagainya. 


\section{F. Informasi}

Informasi adalah data yang diolah menjadi bentuk yang lebih berguna dan lebih berarti bagi penerimanya. Sumber informasi adalah data. Data kenyataannya yang menggambarkan suatu kejadian -kejadian dan kesatuan nyata. Kejadian-kejadian (event) adalah kejadian yang terjadi pada saat tertentu [9].

\section{G. Unifed Modeling Languege (UML)}

Unifed Modeling Languege (UML) adalah bahasa pemodelan untuk sistem atau perangkat lunak yang berparadigma berorientasi objek. Abstraksi konsep dasar UML terdiri dari structural classification, dynamic behavior, dan model management dapat kita pahami main concepts sebagai term yang akan muncul pada sistem membuat diagram dan view adalah katagori dari diagram tersebut. UML mendefinisikan diagram-diagram sebagai Use case diagram, class diagram, statechart diagram, activity diagram, sequence diagram, collaboration diagram, component diagram, dan deployment diagram [10].

UML adalah standar bahasa yang banyak digunakan di dunia industri untuk mendefinisikan requirement, membuat analisis dan desain serta menggambarkan arsitektur dalam pemrograman berorientasi objek [11]. Perancangan perangkat lunak ini menggunakan sistem pemodelan incremental dengan menggunakan empat diagram UML yaitu : Flowchart, Use Case Diagram, Activity Diagram dan Class Diagram. Flowchart.

\section{METODE PENELITIAN}

\subsection{Metode Pengembangan system}

Incremental model adalah pengembangan sistem pada software engineering berdasarkan requirement software yang dipecah menjadi beberapa fungsi atau bagian sehingga model pengembangannya secara bertahap. Tahapan-tahapan dalam metode incremental antara lain sebagai berikut [12]:

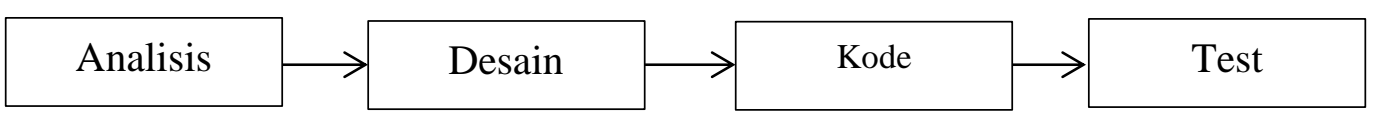

Sumber : Efi Sofiah, Akademi Manajemen Informatika dan Komputer (AMIK) Garut

Gambar 1 pengembangan sistem incremental

\subsection{Analisis}

Analisa suatu sistem bertujuan untuk mengetahui bagaimana sistem tersebut berjalan. Dengan demikian, dapat diketahui dari segi kekurangan maupun kelemahan sebuah sistem yang ada didalamnya[13]. Bahan penelitian yang diperlukan berupa data tempat perikanan yang berada di Bengkulu Selatan. Tahap analisis data adalah suatu kegiatan menganalisa data guna memperoleh suatu klasifikasi data dan permasalahan, serta kebutuhan sistem yang akan digunakan pada proses perancangan sistem yang akan dibangun.

Tabel 1 tempat perikanan di Bengkulu Selatan

\begin{tabular}{ll}
$\begin{array}{l}\text { Nomo } \\
\mathrm{r}\end{array}$ & Nama Tempat Perikanan \\
\hline 1 & Perikanan Juni \\
2 & Perikanan Suarto \\
3 & Perikanan agus \\
4 & Perikanan amin \\
\hline
\end{tabular}


JSAI : Journal Scientific and Applied Informatics

Vol. 4, No. 2, Juni 2021, hal. 248 262

E-ISSN: 2614-3054; P-ISSN: 2614-3062, accredited by Kemenristekdikti, Sinta 5

DOI: 10.36085

\begin{tabular}{ll}
\hline 5 & Perikanan dadang \\
6 & Perikanan asnul \\
7 & Perikanan dahayan \\
8 & Perikanan didi \\
9 & Perikanan pian \\
10 & Perikanan wasrin \\
11 & Perikanan asun \\
12 & Perikanan supirman \\
13 & Perikanan yadi \\
14 & Perikanan yosef \\
15 & Perikanan solehin \\
16 & Perikanan manadi \\
17 & Perikanan rizal \\
18 & Perikanan dayok \\
19 & Perikanan harun \\
20 & Perikanan tanto \\
\hline
\end{tabular}

\subsection{Desain}

a) Flowchart

Flowchart adalah penggambaran secara grafik dari langkah-langkah dan urutan prosedur suatu program. Bagan alir (flowchart) adalah bagan (chart) yang menunjukkan alir (flow)didalam program atau prosedur sistem secara logika. Bagan alir digunakan terutama untuk alat bantu komunikasi dan untuk dokumentasi [14]

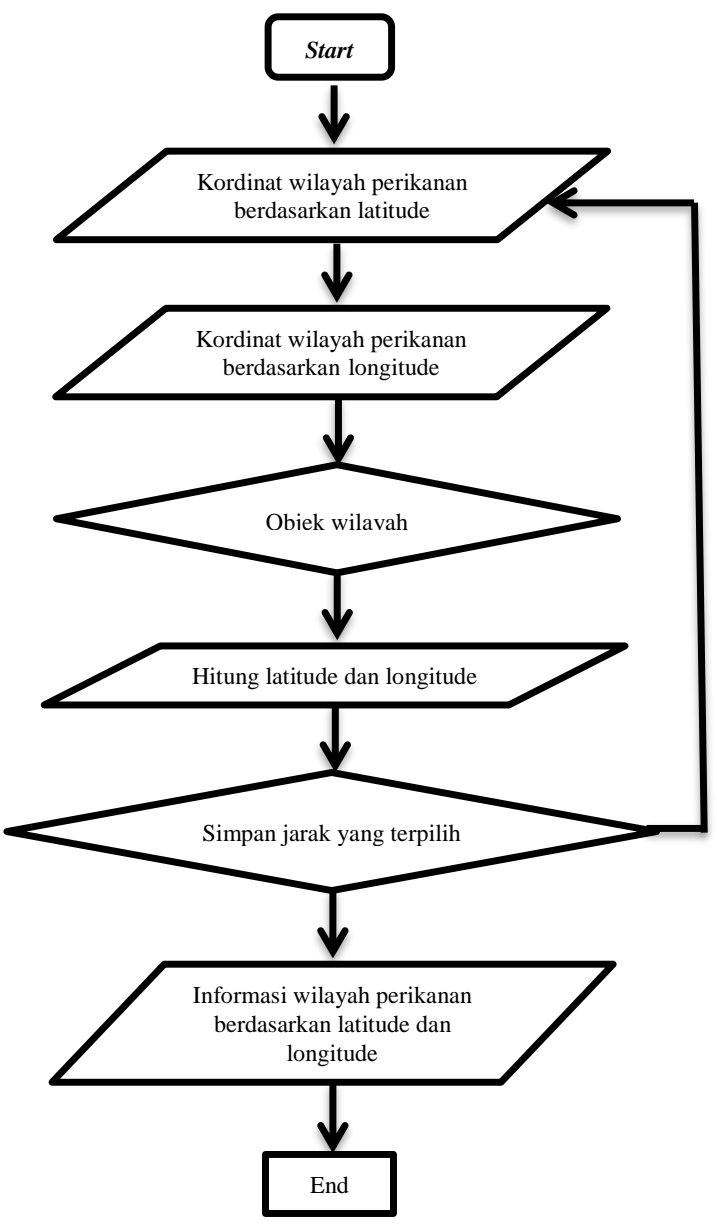

Gambar 2 Flowchart 


\section{b) Use Case Diagram}

Use Case Diagram mendeskripsikan interaksi antara satu atau lebih aktor dengan sistem informasi yang akan dibuat.[15]

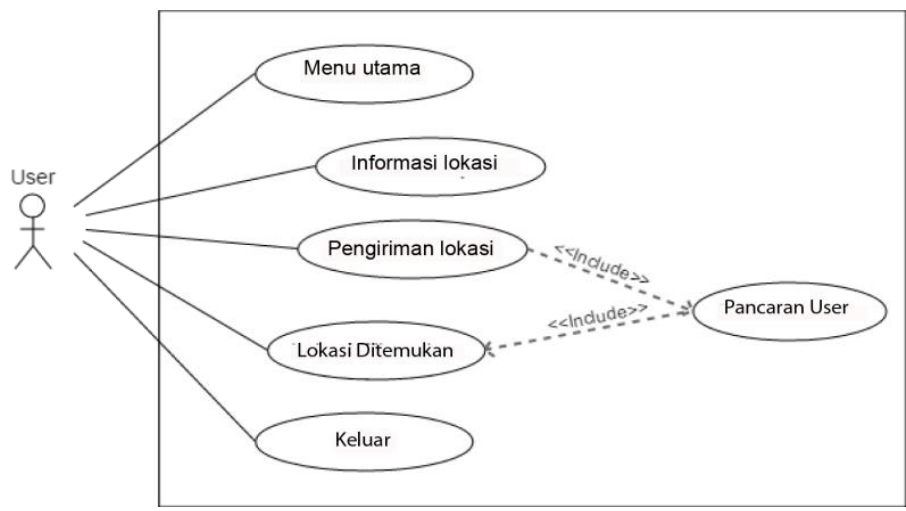

gambar 3 use case diagram

\section{c) Ativity Diagram}

Activity diagram menggambarkan workflow (aliran kerja) atau aktivitas dari sebuah sistem dan user.

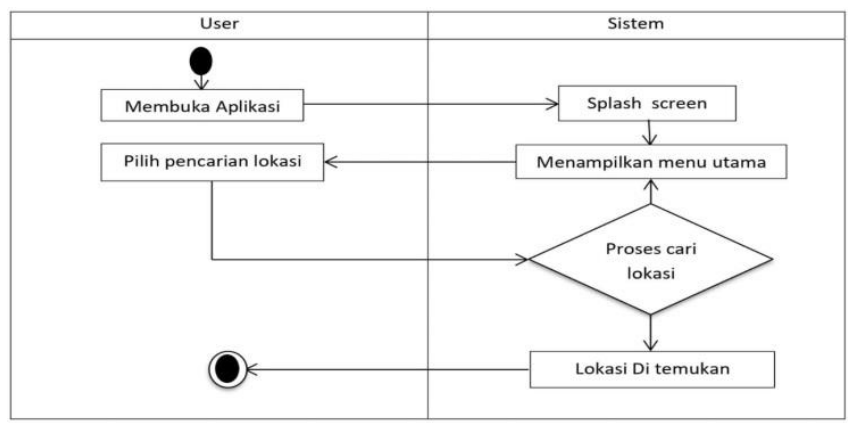

Gambar 4 Activity Diagram

d) Class Diagram

Class Diagram menggambarkan sistem dari segi pendefinisian kelas-kelas yang akan dibuat untuk membangun sistem.

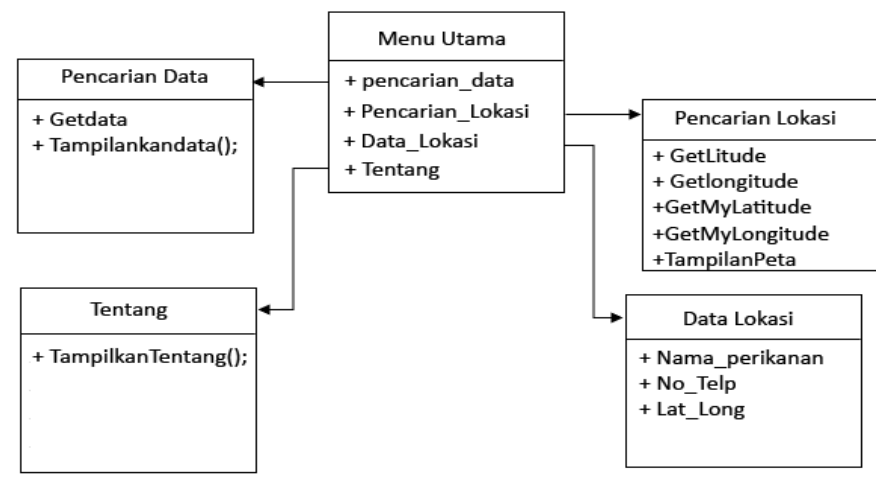

Gambar 5 class diagram 


\section{HASIL DAN ANALISIS}

\subsection{Antar Muka Aplikasi Android}

Antarmuka aplikasi android dari beberapa halaman utama yaitu halaman menu splashscreen, halaman menu utama, kategori perikanan, halaman daftar perikanan, halaman detail perikanan, dan halaman peta.

\section{a) Tampilan SpalshScreen}

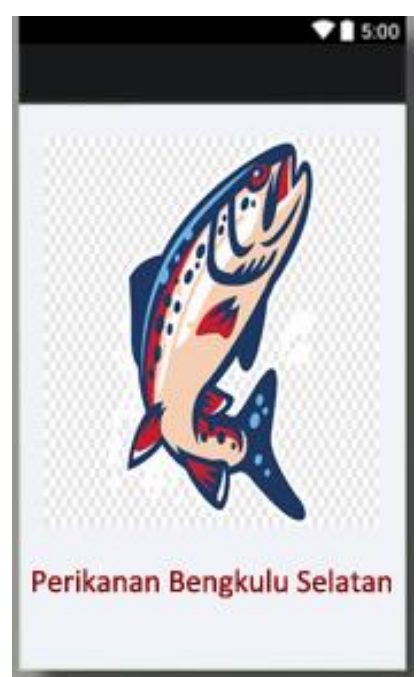

Gambar 6 tampilan splashscreen

\section{b) Halaman Menu Utama}

Antar muka halaman menu utama adalah tampilan utama dari aplikasi yang digunakan pada perangkat mobile, di dalam menu utama terdapat image button dan menu. Implementasi menu utama dapat digambarkan seperti gambar berikut:

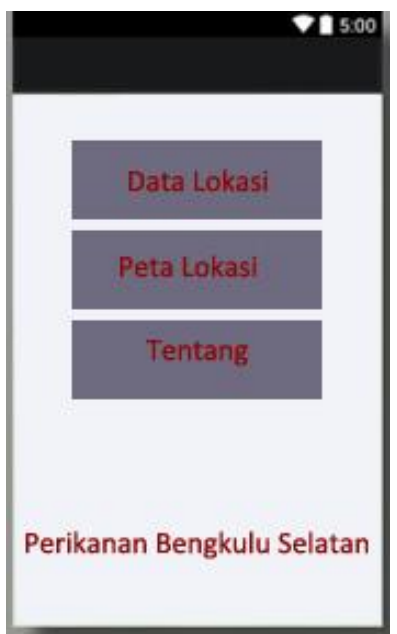

Gambar 7 halaman menu utama 
JSAI : Journal Scientific and Applied Informatics

Vol. 4, No. 2, Juni 2021, hal. 248 262

E-ISSN: 2614-3054; P-ISSN: 2614-3062, accredited by Kemenristekdikti, Sinta 5

DOI: 10.36085

c) Halaman daftar perikanan

Antarmuka halaman daftar perikanan merupakan tampilan data konten yang diimplementasikan kedalam bentuk listview. Implementasi daftar perikanan dapat digambarkan seperti gambar berikut:

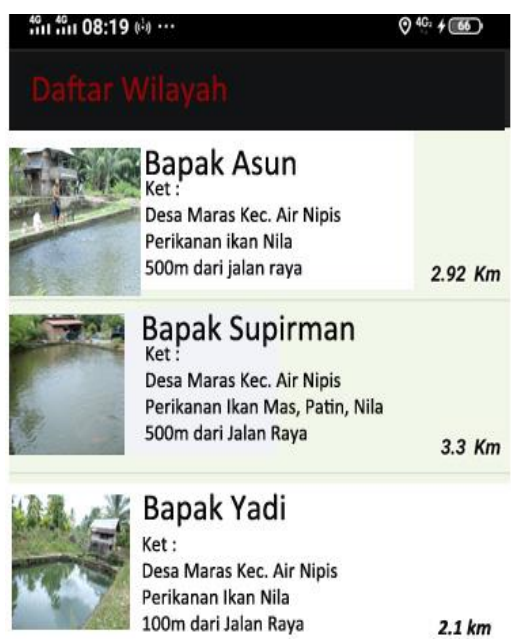

Gambar 8 halaman daftar perikanan

d) Halaman detail perikanan

Antarmuka halaman detail perikanan merupakan tampilan dari rincian konten yang dapat diakses oleh pengguna, dalam antar muka ini terdapat aksi yang dapat dipilih oleh pengguna seperti menelpon, melihat rute dalam peta. Implementasi detail perikanan dapat digambarkan seperti gambar berikut ini:

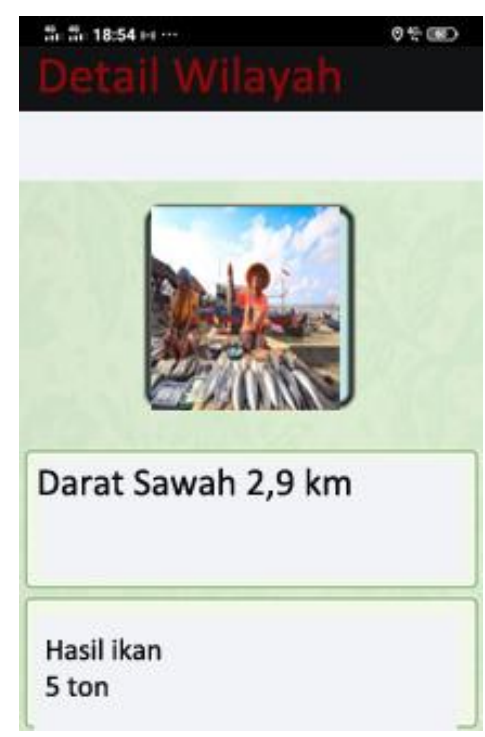

Gambar 9 halaman detail perikanan

e) Halaman Peta

Antarmuka peta merupakan tampilan yang berfungsi untuk menampilkan informasi berupa peta dan menampilkan rute dari posisi pengguna menuju tempat konten yang telah dipilih. Berikut ini tampilan hasil implementasi halaman peta: 


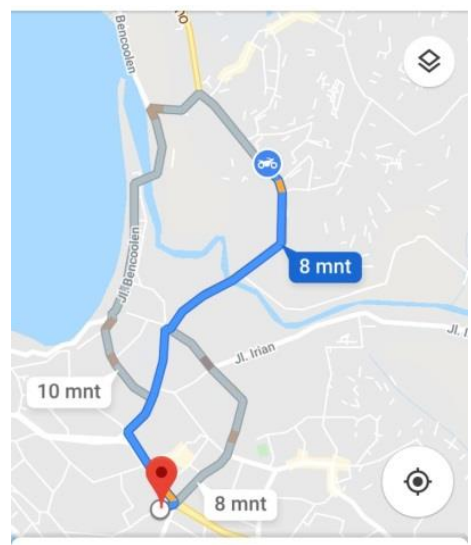

Gambar 10 halaman peta

\subsection{Antar Muka Aplikasi Website}

Antarmuka aplikasi website terdiri dari beberapa halaman utama yaitu halaman menu utama, halaman pengolahan data perikanan, halaman tambah perikanan.

a) Halaman Menu Login

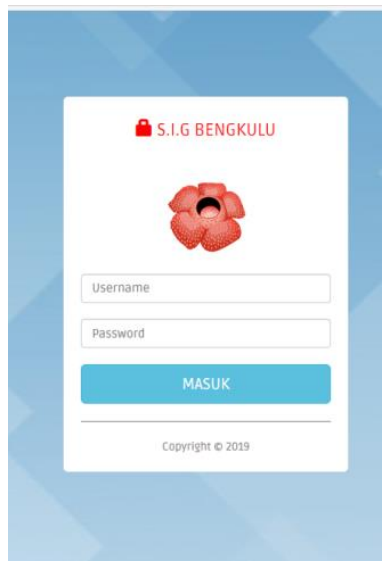

Gambar 11 halaman menu login

b) Halaman Data Perikanan

Berikut adalah tampilan hasil implementasi dari halaman data perikanan. Data perikanan terdapat id, nama perikanan, Golongan serta menu detail, edit dan lokasi.

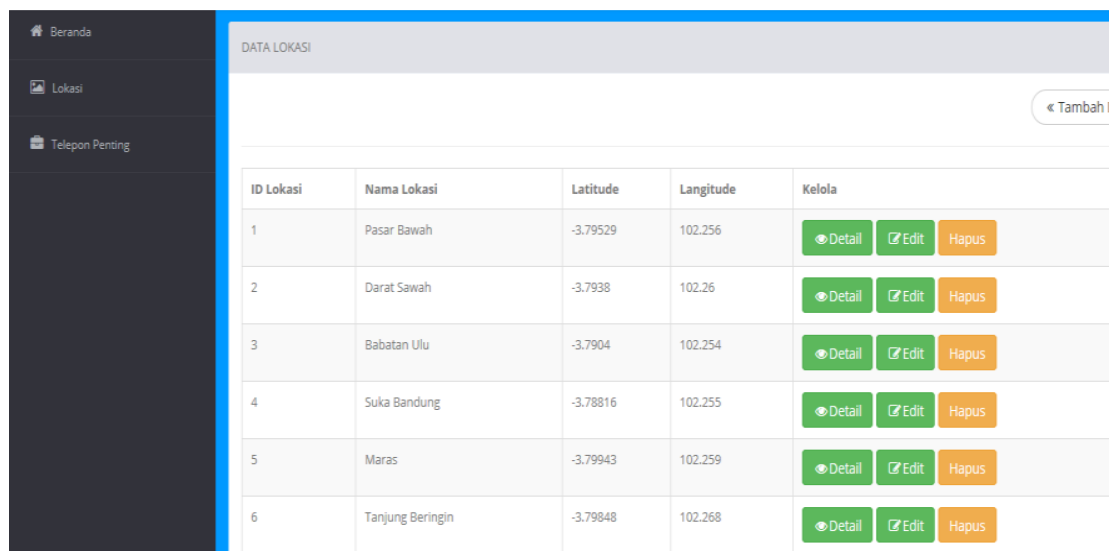

Gambar 12 halaman data perikanan 
JSAI : Journal Scientific and Applied Informatics

Vol. 4, No. 2, Juni 2021, hal. 248 262

E-ISSN: 2614-3054; P-ISSN: 2614-3062, accredited by Kemenristekdikti, Sinta 5

DOI: 10.36085

c) Halaman Input Data Perikanan

Berikut ini tampilan hasil implementasi dari halaman Input data perikanan terdiri dari nama, kategori, latitude dan longitude untuk posisi perikanan.

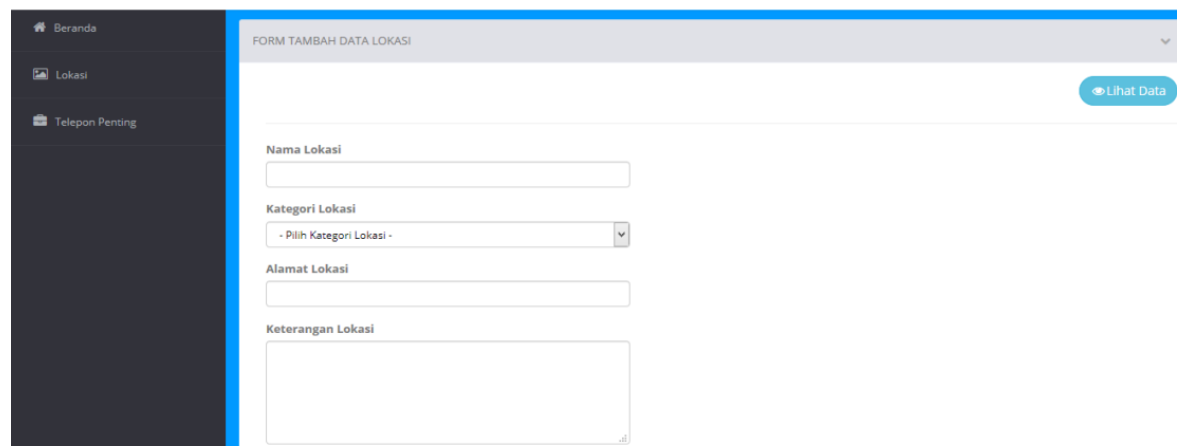

Gambar 13 halaman input data perikanan

4. Hasil Pengujian

Hasil pengujian adalah hasil dari pengujian terhadap fungsi-fungsi yang ada di dalam sistem, apakah fungsional dari aplikasi tersebut berfungsi sesuai yang diharapkan atau tidak. Pada tahapan ini pengujian akan dilakukan dengan tiga teknik, yaitu : Black Box Testing, White Box Testing dan User Aceptance Test. Pengujian dilakukan agar nantinya dapat dilihat kelayakan sistem yang dihasilkan dan akan digunakan.

a) Black Box Testing

Tabel 2 hasil pengujian aplikasi dengan black box

\begin{tabular}{|l|l|c|c|}
\hline \multicolumn{4}{|c|}{ Pengujian Aplikasi Android } \\
\hline Item Uji & Detail Uji & Jenis Uji & Hasil \\
\hline Pencarian Konten & Keyword & Black box & Sukses \\
\hline Pilih Kategori & Menu Kategori & Black box & Sukses \\
\hline Pilih Konten & Menu konten & Black box & Sukses \\
\hline Intent (Aksi) & Peta & Black box & Sukses \\
\cline { 2 - 4 } & Direction & Black box & Sukses \\
\cline { 2 - 4 } & Call & Black box & Sukses \\
\hline \multirow{5}{*}{ Peta } & Zoom in & Black box & Sukses \\
\cline { 2 - 4 } & Out & Black box & Sukses \\
\cline { 2 - 4 } & Street View & Black box & Sukses \\
\cline { 2 - 4 } & Earth View & Black box & Sukses \\
\hline Direction & Direction & Black box & Sukses \\
\hline \multirow{4}{*}{ Item Uji } & Pengujian Aplikasi Website & \\
\hline Tambah Kategori & Detail Uji & Jenis Uji & Hasil \\
\cline { 2 - 4 } & GamaKategori & Black box & Sukses \\
\hline Edit Kategori & Nama Kategori & Black box & Sukses \\
\cline { 2 - 4 } & Gambar Kategori & Black box & Sukses \\
\hline Lokasi Kategori & Lokasi & Black box & Sukses \\
\hline Tambah Konten & Judul Konten & Black box & Sukses \\
\cline { 2 - 4 } & Telpon & Black box & Sukses \\
\hline
\end{tabular}


JSAI : Journal Scientific and Applied Informatics

Vol. 4, No. 2, Juni 2021, hal. 248 262

E-ISSN: 2614-3054; P-ISSN: 2614-3062, accredited by Kemenristekdikti, Sinta 5

\begin{tabular}{|l|l|l|l|}
\hline \multirow{7}{*}{} & Deskripsi Singkat & Black box & Sukses \\
\cline { 2 - 4 } & Deskripsi Lengkap & Black box & Sukses \\
\cline { 2 - 4 } & Gambar1 & Black box & Sukses \\
\cline { 2 - 4 } & Gambar2 & Black box & Sukses \\
\cline { 2 - 4 } & Alamat & Black box & Sukses \\
\cline { 2 - 4 } & Latitude & Black box & Sukses \\
\cline { 2 - 4 } & Longitude & Black box & Sukses \\
\hline Ubah Konten & Judul Konten & Black box & Sukses \\
\hline \multirow{7}{*}{} & Telpon & Black box & Sukses \\
\cline { 2 - 4 } & Deskripsi Singkat & Black box & Sukses \\
\cline { 2 - 4 } & Deskripsi Lengkap & Black box & Sukses \\
\hline
\end{tabular}

Tabel 3 pengujian menu utama

\begin{tabular}{|c|c|c|c|c|c|c|}
\hline $\begin{array}{c}\text { Modul yang } \\
\text { diuji }\end{array}$ & $\begin{array}{c}\text { Prosedur } \\
\text { Pengujian }\end{array}$ & Masuk kan & $\begin{array}{c}\text { Keluaran yang } \\
\text { diharapkan }\end{array}$ & Hasil Yang Didapat & Kesimpulan & Hasil \\
\hline Menu Utama & $\begin{array}{c}\text { Pengguna } \\
\text { mengklik ikon } \\
\text { aplikasi }\end{array}$ & $\begin{array}{c}\text { Klik ikon } \\
\text { plikasi }\end{array}$ & $\begin{array}{c}\text { Tampil menu dari } \\
\text { aplikasi }\end{array}$ & $\begin{array}{c}\text { Tampil menu utama } \\
\text { dari aplikasi }\end{array}$ & Baik & Sukses \\
\hline Menu wilayah & $\begin{array}{c}\text { Pengguna } \\
\text { mengklik } \\
\text { menu } \\
\text { wilayah }\end{array}$ & $\begin{array}{c}\text { Klik } \\
\text { tombol } \\
\text { menu } \\
\text { Wilayah }\end{array}$ & $\begin{array}{c}\text { Tampil halaman } \\
\text { wilayah }\end{array}$ & $\begin{array}{c}\text { Tampil halaman } \\
\text { wilayah }\end{array}$ & Baik & Sukses \\
\hline $\begin{array}{c}\text { Menu tentang } \\
\text { aplikasi }\end{array}$ & $\begin{array}{c}\text { Pengguna } \\
\text { mengklik } \\
\text { menu tentang } \\
\text { aplikasi }\end{array}$ & $\begin{array}{c}\text { Klik tombol } \\
\text { menu } \\
\text { tentang } \\
\text { Aplikasi }\end{array}$ & $\begin{array}{c}\text { Tampil halaman } \\
\text { tentang aplikasi }\end{array}$ & $\begin{array}{c}\text { Tampil halaman } \\
\text { tentang aplikasi }\end{array}$ & Baik & Sukses \\
\hline
\end{tabular}

Tabel 4 pengujian menu login admin

\begin{tabular}{|c|c|c|c|c|c|c|}
\hline $\begin{array}{l}\text { Modul yang } \\
\text { diuii }\end{array}$ & Prosedur Pengujian & Masuk kan & $\begin{array}{l}\begin{array}{l}\text { Keluaran yang } \\
\text { diharapkan }\end{array} \\
\text {. }\end{array}$ & Hasil Yang Didapat & Kesimpulan & Hasil \\
\hline \multirow[t]{4}{*}{$\begin{array}{c}\text { Login } \\
\text { Admin }\end{array}$} & $\begin{array}{l}\text { Akses } \\
\text { halaman } \\
\text { utama }\end{array}$ & $\begin{array}{l}\text { Klik menu login } \\
\text { aplikasi }\end{array}$ & $\begin{array}{l}\text { Tampil menu login dari } \\
\text { aplikasi }\end{array}$ & $\begin{array}{c}\text { Membuka } \\
\text { Halaman untuk } \\
\text { memasukkan } \\
\text { username dan } \\
\text { password } \\
\end{array}$ & $\begin{array}{c}\text { Membuka } \\
\text { Halaman untuk } \\
\text { memasukkan } \\
\text { username dan } \\
\text { password } \\
\end{array}$ & Sukses \\
\hline & Klik login & $\begin{array}{l}\text { Klik menu login } \\
\text { aplikasi }\end{array}$ & $\begin{array}{l}\text { Tampil menu login dari } \\
\text { aplikasi }\end{array}$ & $\begin{array}{l}\text { Apabila user name salah, } \\
\text { password benar tidak dapat } \\
\text { mengakses web }\end{array}$ & $\begin{array}{c}\text { Apabila user name } \\
\text { salah, password } \\
\text { benar tidak dapat } \\
\text { mengakses web } \\
\end{array}$ & Sukses \\
\hline & & & & $\begin{array}{c}\text { User name benar,password } \\
\text { salah tidak dapat mengakses } \\
\text { web }\end{array}$ & $\begin{array}{c}\text { User name } \\
\text { benar, password } \\
\text { salah tidak dapat } \\
\text { mengakses web }\end{array}$ & Sukses \\
\hline & & & & $\begin{array}{c}\text { User name salah, password } \\
\text { salah tidak dapat mengakses } \\
\text { web } \\
\text { User name benar, password } \\
\text { benar dapat mengakses web }\end{array}$ & $\begin{array}{l}\text { User name salah, } \\
\text { password salah tidak } \\
\text { dapat mengakses } \\
\text { web } \\
\text { User name benar, } \\
\text { password benar dapat } \\
\text { mengakses web }\end{array}$ & \\
\hline
\end{tabular}

Tabel 5 pengujian melakukan pencarian perikanan

\begin{tabular}{|c|c|c|c|c|c|c|}
\hline Modul yang diuji & $\begin{array}{c}\text { Prosedur } \\
\text { Pengujian }\end{array}$ & $\begin{array}{c}\text { Masuk } \\
\text { kan }\end{array}$ & $\begin{array}{c}\text { Keluaran yang } \\
\text { diharapkan }\end{array}$ & Hasil Yang Didapat & Kesimpulan & Hasil \\
\hline Mencari & $\begin{array}{c}\text { Pengguna } \\
\text { mengklik radio } \\
\text { button }\end{array}$ & $\begin{array}{c}\text { Klik salah } \\
\text { satu radio } \\
\text { button } \\
\text { berdasarka } n \\
\text { golongan } \\
\text { dan klik cari }\end{array}$ & $\begin{array}{c}\text { Tampil Pin lokasi } \\
\text { perikanan }\end{array}$ & $\begin{array}{c}\text { Tampil pin lokasi } \\
\text { perikanan }\end{array}$ & Baik & Sukses \\
\hline
\end{tabular}


JSAI : Journal Scientific and Applied Informatics

Vol. 4, No. 2, Juni 2021, hal. 248 262

E-ISSN: 2614-3054; P-ISSN: 2614-3062, accredited by Kemenristekdikti, Sinta 5 DOI: 10.36085

\begin{tabular}{|c|c|c|c|c|c|}
\hline $\begin{array}{c}\text { Melihat informasi } \\
\text { perikanan }\end{array}$ & $\begin{array}{c}\text { Pengguna } \\
\text { mengklik Pin } \\
\text { yang ada di maps }\end{array}$ & $\begin{array}{c}\text { Klik salah } \\
\text { satu pin } \\
\text { perikanan }\end{array}$ & $\begin{array}{c}\text { Tampil detail } \\
\text { informasi } \\
\text { perikanan }\end{array}$ & $\begin{array}{c}\text { Tampil detail } \\
\text { informasi perikanan }\end{array}$ & Baik \\
\hline $\begin{array}{c}\text { Telepon } \\
\text { perikanan }\end{array}$ & $\begin{array}{c}\text { Pengguna } \\
\text { informasi } \\
\text { perikanan }\end{array}$ & $\begin{array}{c}\text { Klik detail } \\
\text { informasi } \\
\text { perikanan }\end{array}$ & $\begin{array}{c}\text { Membuka jendela } \\
\text { telepon }\end{array}$ & $\begin{array}{c}\text { Membuka jendela } \\
\text { telepon }\end{array}$ & Baik \\
\hline
\end{tabular}

Tabel 6 pengujian memasukan perikanan

\begin{tabular}{|c|c|c|c|c|c|c|}
\hline $\begin{array}{c}\text { Modul yang } \\
\text { diuji }\end{array}$ & $\begin{array}{l}\text { Prosedur } \\
\text { Pengujian }\end{array}$ & Masuk kan & $\begin{array}{c}\text { Keluaran yang } \\
\text { diharapkan }\end{array}$ & $\begin{array}{r}\text { Hasil Yang } \\
\text { Didapat }\end{array}$ & Kesimpulan & Hasil \\
\hline $\begin{array}{c}\text { Memasukan } \\
\text { informasi ke } \\
\text { dalam formulir } \\
\text { wilayah } \\
\end{array}$ & $\begin{array}{c}\text { Pengguna } \\
\text { mengisi nama, } \\
\text { umur, dan nomor } \\
\text { telepon } \\
\end{array}$ & Klik simpan & $\begin{array}{l}\text { Data berhasil } \\
\text { disimpan }\end{array}$ & $\begin{array}{l}\text { Data berhasil } \\
\text { disimpan }\end{array}$ & Baik & Sukses \\
\hline $\begin{array}{c}\text { Memasukkan } \\
\text { informasi ke dalam } \\
\text { formulir wilayah }\end{array}$ & $\begin{array}{c}\text { Pengguna } \\
\text { memilih } \\
\text { golongan dari } \\
\text { listview }\end{array}$ & $\begin{array}{l}\text { Pengguna } \\
\text { mengkl ik } \\
\text { golonga } \mathrm{n}\end{array}$ & Tidak terjadi error & Tidak terjadi error & Baik & Sukses \\
\hline $\begin{array}{c}\text { Kembali ke menu } \\
\text { utama }\end{array}$ & $\begin{array}{c}\text { Pengguna } \\
\text { memilih button } \\
\text { kembali }\end{array}$ & $\begin{array}{c}\text { Penggu na } \\
\text { mengkl ik } \\
\text { button kembali }\end{array}$ & $\begin{array}{c}\text { Kembali ke menu } \\
\text { utama }\end{array}$ & $\begin{array}{c}\text { Kembali ke menu } \\
\text { utama }\end{array}$ & Baik & Sukses \\
\hline
\end{tabular}

Tabel 7 pengujian tentang mengakses aplikasi

\begin{tabular}{|c|c|c|c|c|c|c|}
\hline $\begin{array}{c}\text { Modul yang } \\
\text { Diuji }\end{array}$ & $\begin{array}{c}\text { Prosedur } \\
\text { Pengujian }\end{array}$ & Masukkan & $\begin{array}{c}\text { Keluaran yang } \\
\text { diharapkan }\end{array}$ & $\begin{array}{c}\text { Hasil Yang } \\
\text { Didapat }\end{array}$ & Kesimpul an \\
\hline Tentang aplikasi & $\begin{array}{c}\text { Memilih menu } \\
\text { tentang aplikasi }\end{array}$ & $\begin{array}{c}\text { Pengguna } \\
\text { mengklik } \\
\text { button tentang } \\
\text { Aplikasi }\end{array}$ & $\begin{array}{c}\text { Menampilkan } \\
\text { halaman tentang } \\
\text { aplikasi }\end{array}$ & $\begin{array}{c}\text { Menampil kan halaman } \\
\text { tentang } \\
\text { aplikasi }\end{array}$ & Baik \\
\hline
\end{tabular}

b) White Box Testing

1) Listing Program lokasi

Tabel 8 listing program aplikasi

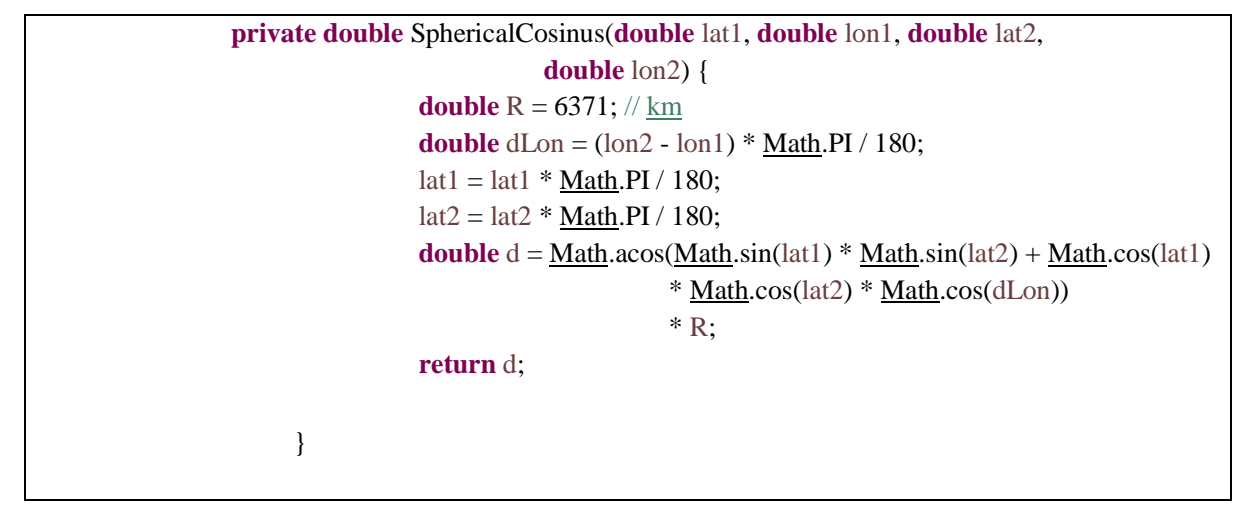

2) Flowchart lokasi 
JSAI : Journal Scientific and Applied Informatics

Vol. 4, No. 2, Juni 2021, hal. 248 262

E-ISSN: 2614-3054; P-ISSN: 2614-3062, accredited by Kemenristekdikti, Sinta 5 DOI: 10.36085

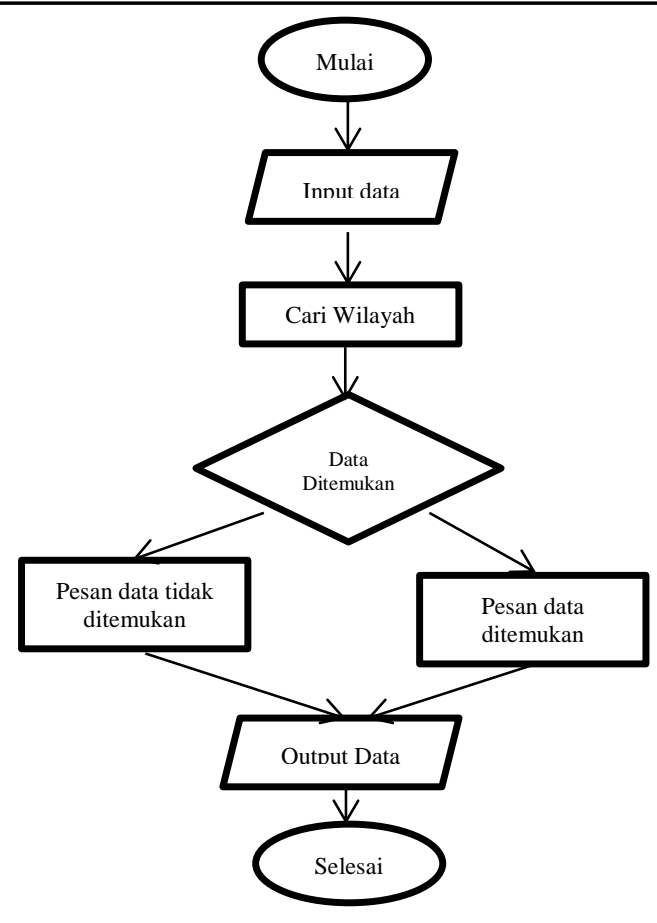

Gambar 14 flowchart lokasi

3) Flowgraph Lokasi

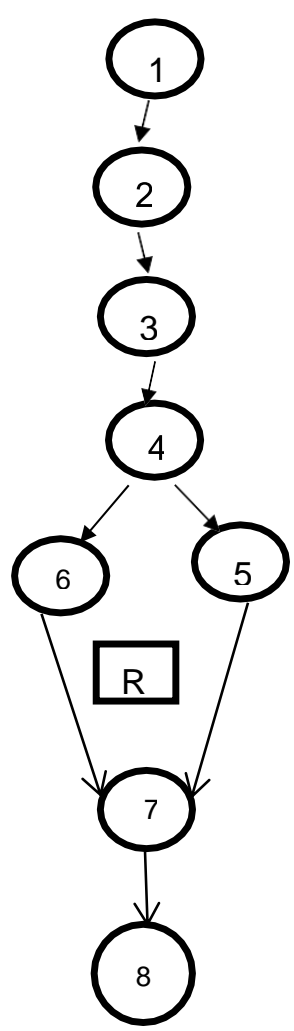

Gambar 15 Flowgraph Lokasi

4) Gramph Matrix 
JSAI : Journal Scientific and Applied Informatics

Vol. 4, No. 2, Juni 2021, hal. 248 262

E-ISSN: 2614-3054; P-ISSN: 2614-3062, accredited by Kemenristekdikti, Sinta 5

DOI: 10.36085

Tabel 9 Gramph Matrix

\begin{tabular}{|l|l|l|l|l|l|l|l|l|}
\hline & 1 & 2 & 3 & 4 & 5 & 6 & 7 & 8 \\
\hline 1 & & 1 & & & & & & \\
\hline 2 & & & 1 & & & & & \\
\hline 3 & & & & 1 & & & & \\
\hline 4 & & & & & 1 & & & \\
\hline 5 & & & & & & 1 & & \\
\hline 6 & & & & & & & 1 & 1 \\
\hline 7 & & & & & & & & \\
\hline 8 & & & & & & & & \\
\hline
\end{tabular}

c) Pengujian UAT (User Aceptance Test)

Tabel 10 pengujian UAT (User Aceptance Test)

\begin{tabular}{|c|l|c|}
\hline \multicolumn{2}{|c|}{ PENGUJIAN SISTEM PENGGUNA } \\
\hline NO & \multicolumn{1}{|c|}{ PERTANYAAN } & \\
\hline 1 & Apakah tampilan pada sistem ini menarik? & \\
\hline 2 & Apakah tampilan aplikasi pencarian wilayah perikanan ini mudah dipahami? & \\
\hline 3 & $\begin{array}{l}\text { Apakah lokasi yang ditampilkan pada aplikasi pencarian wilayah perikanan bermanfaat menurut } \\
\text { anda? }\end{array}$ & \\
\hline 4 & $\begin{array}{l}\text { Apakah aplikasi pencarian wilayah perikanan ini dapat membantu anda untuk mencari lokasi } \\
\text { wilayah perikanan }\end{array}$ & \\
\hline 5 & Apakah aplikasi pencarian wilayah perikanan memberikan respon yang cepat? & \\
\hline 6 & $\begin{array}{l}\text { Apakah rute yang ditampilkan untuk menuju lokasi perikanan tersebut akurat dan mudah } \\
\text { dimengerti }\end{array}$ & \\
\hline 7 & Apakah saat aplikasi ini dijalankan tidak terdapat error? & \\
\hline 8 & $\begin{array}{l}\text { Setelah menggunakan aplikasi pencarian wilayah perikanan ini, apakah anda puas dalam memilih } \\
\text { lokasi yang diinginkan? }\end{array}$ & \\
\hline 9 & Apakah aplikasi ini bersifat user friendly (mudah digunakan)? & \\
\hline 10 & $\begin{array}{l}\text { Apakah anda akan merekemondasikan aplikasi pencarian wilayah perikanan ke relasi atau kerabat } \\
\text { anda }\end{array}$ & \\
\hline
\end{tabular}

Dari tabel persentase hasil pengujian di atas dapat disimpulkan untuk pengujian sistem memiliki persentase sesuai sebesar $80 \%$ dari 20 user yang dilakukan. Selanjutnya untuk tidak sesuai memiliki persentase sebesar $20 \%$ dari 20 pengujian yang dilakukan. 


\section{KESIMPULAN}

Adapun kesimpulan yang dapat diambil dari penelitian ini adalah sebagai berikut:

Aplikasi ini memudahkan pengguna dalam mencari lokasi perikanan yang dibutuhkan yang sesuai dengan yang diinginkan. Dengan LBS (Location Based Service) mempercepat pengguna dalam melakukan pencarian keberadaan lokasi dan data-data perikanan. Apabila tidak ada jaringan internet, Aplikasi ini tidak akan menampilkan informasi, data, peta lokasi perikanan.

\section{REFERENSI}

[1] A. Andani, M. Z. Yuliarso, and S. Widiono, "Analisis Pendapatan Dan Resiko Usaha Budidaya Ikan Air Tawar Di Kabupaten Bengkulu Selatan,” J. AGRISEP, vol. 13, no. 1, pp. 67-74, 2014, doi: 10.31186/jagrisep.13.1.67-74.

[2] A. Wijaya, "Pembuatan Aplikasi Panggilan Darurat Berbasis Android Menggunakan Location Based Services," JSAI (Journal Sci. Appl. Informatics), vol. 2, no. 1, pp. 97-104, 2019, doi: 10.36085/jsai.v2i1.72.

[3] A. Muthohari, H. Bunyamin, and S. Rahayu, "Pengembangan Aplikasi Kasir Pada Sistem Informasi Rumah Makan Padang Ariung," J. Algoritm., vol. 13, no. 1, pp. 157-163, 2016, doi: 10.33364/algoritma/v.13-1.157.

[4] N. Agustina, S. Risnanto, and I. Supriadi, "Pengembangan Aplikasi Location Based Service Untuk Informasi Dan Pencarian Lokasi Pariwisata Di Kota Cimahi Berbasis Android," J. Ilm. Teknol. Infomasi Terap., vol. 3, no. 1, 2016, doi: 10.33197/jitter.vol3.iss1.2016.121.

[5] A. Mudzakir and R. Arifudin, "Aplikasi Location Based Service Fasilitas Umum Berbasis Android," Unnes J. Math., vol. 4, no. 2, 2015, doi: 10.15294/ujm.v4i2.10464.

[6] A. Fauzi, "Penerapan Location-Based Service pada Layanan Informasi Budaya Indonesia di Perangkat Mobile," Fakt. Exacta, vol. 8, no. 3, pp. 250-260, 2015, [Online]. Available: http://journal.lppmunindra.ac.id/index.php/Faktor_Exacta/article/view/325.

[7] E. S. Han and A. goleman, daniel; boyatzis, Richard; Mckee, “済無No Title No Title,” J. Chem. Inf. Model., vol. 53, no. 9, pp. 1689-1699, 2019.

[8] J. Andi, "Pembangunan Aplikasi Child Tracker Berbasis Assisted - Global Positioning System ( A-GPS ) Dengan Platform Android," J. Ilm. Komput. dan Inform., vol. 1, no. 1, pp. 1-8, 2015, [Online]. Available: elib.unikom.ac.id/download.php?id=300375.

[9] T. A. Smith, “No Title血清及尿液特定蛋白检测在糖尿病肾病早期诊断中的意义,s” vol. 3, no. August, 2016.

[10] S. Sutejo, "Pemodelan UML Sistem Informasi Geografis Pasar Tradisional Kota Pekanbaru," Digit. Zo. J. Teknol. Inf. dan Komun., vol. 7, no. 2, pp. 89-99, 2016, doi: 10.31849/digitalzone.v7i2.600.

[11] Nur'Ainun, Hartono, and Jimmy, "Perancangan Aplikasi Mobile Repository Skripsi (Skripsi ALumni Mahasiswa) STMIK IBBI Medan Berbasis Android," J. Ilm. CORE IT, vol. 5, no. 2, pp. 18-27, 2017.

[12] Abdul Khadir, "Sistem Pendukung Keputusan," Sist. Pendukung Keputusan, vol. 8, pp. 1-7, 2014.

[13] N. A. Pratama and C. Hermawan, "Aplikasi Pembelajaran Tes Potensi Akademik Berbasis Android," J. Penelit. Dosen FIKOM, vol. 6, no. 1, pp. 1-6, 2016.

[14] Verawati and P. D. Liksha, "Aplikasi Akuntansi Pengolahan Data Jasa Service Pada Pt. Budi Berlian Motor Lampung,” J. Sist. Inf. Akunt., vol. 1, no. 1, pp. 1-14, 2018.

[15] A. Aris, R. Anggara, and Z. A. Zamzami, "Perancangan Sistem Informasi Penerimaan Siswa Baru Berbasis Web Pada PKBM Bhakti Sejahtera,” Cices, vol. 2, no. 1, pp. 87-98, 2016, doi: 10.33050/cices.v2i1.215. 